\title{
Changes Land Use in Land Consolidation Area in Seminyak, Kuta
}

\author{
Magister Architecture \\ Faculty of Engineering, Udayana University \\ Denpasar, Bali \\ suryabuana78@gmail.com \\ Architecture Department \\ Faculty of Engineering, Udayana University \\ Denpasar, Bali \\ Architecture Department \\ Faculty of Engineering, Udayana University \\ Denpasar, Bali
}

Anak Agung Putu Surya Buana ${ }^{1}$, Ida Bagus Gde Wirawibawa ${ }^{2}$, Ni Ketut Agusintadewi ${ }^{3}$

\begin{abstract}
Land Consolidation (LC), is the government's solution in land acquisition for development. In addition, LC aims to improve the quality of the environment by rearranging plots of land to be more organized and equipped with environmental infrastructure, as well as land tenure in accordance with land use plans. The location of the land consolidation area in Seminyak Village which is close to the center of government, economy and tourism has implications for land use in the area. The phenomenon of land use that occurs in this region tends to ignore the spatial planning that has been determined by the government. If this condition is left unchecked, there will be more violations of land use that are not in accordance with the spatial allocation, leading to spatial conflicts and clutter in regional spatial planning. This study aims to identify changes in land use in the area of land consolidation in the Seminyak Village and the dominant factors underlying the changes in land use. Qualitative methods are used to identify changes in land use, and these dominant factors. Primary data obtained from observations, direct documentation, and the results of interviews with informants determined by purposive sampling. The results showed that there was a mismatch of land use with the plan for spatial planning in the area designated for settlement and green open space. The dominant factors underlying the changes in land use are law enforcement, then environmental factors, economic factors, and socio-cultural factors. The results of this study can be input for the government in formulating policies relating to planning and controlling the use of space in order to create safe, comfortable and sustainable use of space.
\end{abstract}

Index Terms — land consolidation, land use, land use change

\section{INTRODUCTION}

The high population growth in urban areas causes various problems in the land sector. The increase in population results in an increased need for land [1]. The availability of adequate housing and adequate facilities and infrastructure, such as roads and public spaces, is a tough homework for the government. Limited government-owned land causes development activities to be hampered, because most of the existing land belongs to the community. Urban land consolidation is an alternative land acquisition for development and arrangement of settlements, without

having to displace land owners [2]. Development is not only the responsibility of the government, but also requires cooperation between stakeholders. Through the land consolidation program, it is hoped that a mutually beneficial relationship between land owners and the government is expected so that development activities do not harm anyone. Land consolidation (Land Consolidation or LC) is a development method that is applied as one of the policies to regulate land tenure in accordance with land use plans and land acquisition for development purposes [3].

Seeing the success of the LC program in providing land for development in several areas, the Provincial 
Government of Bali in 1995 carried out urban LC activities in parts of the Seminyak Village, Kuta District. The results of these LC activities are the increasing environmental quality with organized land forms and fields, good accessibility, availability of public facilities and supporting infrastructure through active participation of the community in the provision of land [4]. LC activities aim to realize an order of control, ownership, use, and land use in accordance with the land use plan.

Based on the Badung Regency Regional Regulation Number 26 of 2013 concerning the 2013-2033 Badung Regency Spatial Plan, the LC Seminyak area is an area where most of the zoning is used for residential areas and service trade areas. In residential areas, buildings that are allowed are residential houses, small-scale commercial buildings, public buildings, including public service buildings, government, education, worship and gardening. The increase in the number of tourist arrivals coming to Bali causes an increase in the demand for accommodation and tourism support facilities [5]. This condition causes a tendency to use land to meet these needs, without paying attention to the spatial plan of the area. This has led to the emergence of spatial use that is not in accordance with the established Regional Spatial Layout Plan.

If this condition is not resolved, it is feared that there will be many violations of land use and utilization that are not in accordance with spatial planning, and have the potential to cause spatial conflicts and chaos in spatial planning. Based on this phenomenon, this research is important to determine the development of land use in the land consolidation area in the Village of Seminyak, so that the factors behind changes in land use can be identified.

\section{METHOD}

This research uses a qualitative approach. Qualitative methods are used to understand land use changes that occur after the implementation of land consolidation activities in the Seminyak LC Area. Primary data is obtained from interviews and direct observation at the research location, while secondary data can be in the form of time series satellite imagery maps, administrative maps, land parcels maps, spatial pattern maps for the Badung Regency Spatial Plan, and local regulations related to land use Seminyak Village, Badung Regency. The research begins with a grand tour to the research location, followed by a literature study on land consolidation, land use change and the factors behind land use change. Field observations, documentation, and use of time series imagery maps from Google Earth and mapping techniques are used to determine developments and changes in land use in the study area.

To find out the factors behind the change in land use, interviews were carried out. The selected sources are based on purposive sampling technique, with the main criteria being that potential sources have an interest in and have a deep understanding of something that is being researched, or become part of the process. This consideration is made to be able to support the search for answers to research questions [6]. The selected resource persons were divided into four groups: (1) 8 indigenous people, who are residents from or outside of Seminyak Village who owned land prior to the LC Seminyak activities; (2) the population of migrants is 8 people; (3) 3 community figures or leaders (4) local government agencies consisting of the Public Works and Spatial Planning Office, the Land Office, PMPTSP Service, and Badung Regency Satpol PP.

\section{LITERATURE}

According to Anitasari [7], land use change or land use change is an activity to change the new use of land from an activity to another. Ariani [8] states that changes in land use are changes in functions that occur on land in different periods of time. Meanwhile, Sadyohutomo [9] argues that land use change refers to two different things: previous land use and land use based on spatial planning. Change that refers to the previous land use is a new use of land that is different from the previous land use. Changes that refer to the spatial planning plan are new uses of land, which are not in accordance with the provisions in the legalized spatial plan. Based on the above definition, a change in land use is a new use of land or a change in function that occurs on a land, resulting in a mismatch between land use and the legalized regional spatial plan.

Changes in land use that occur from time to time are in line with the increasing population growth which directly impacts the increased demand for land [10]. According to Kustiwan [11] and Lestari [12], the factors that cause changes in land use or land use change that occur are caused by three factors: external factors, internal factors, and policy factors. Meanwhile, Lee 1979 in Yunus [13] states that changes in land use in an area, particularly settlement development and the development of other non-agricultural functions are influenced by several factors, including; the existence of public utilities, the level of land accessibility, the existence of regulations regarding land use, the physical characteristics of the land, the characteristics of the land owner, and the role of the developer.

\section{DATA AND ANALYSIS}

\section{A. Overview}

Kelurahan Seminyak is one of the sub-districts located in Kuta District, with an area of \pm 265 ha. Administratively, the boundaries of the area of Kelurahan Kuta are: the east is bordered by Denpasar City, the south is bordered by the Kelurahan Legian, the west is bordered by the Bali Strait, in the north the north is bordered by the Kelod Kerobokan Kelod. The research location was focused on the area of Seminyak Village which had been the target of land consolidation activities covering an area of \pm 92.53 ha. The LC Seminyak area is an area located at the northern tip of Kuta District and directly adjacent to Denpasar City. This area has a very strategic location when viewed from its 
accessibility with the centers of government, economy and tourism, because it is traversed by Jalan Sunset Road which is an arterial road and connects the Central Badung area with South Badung.

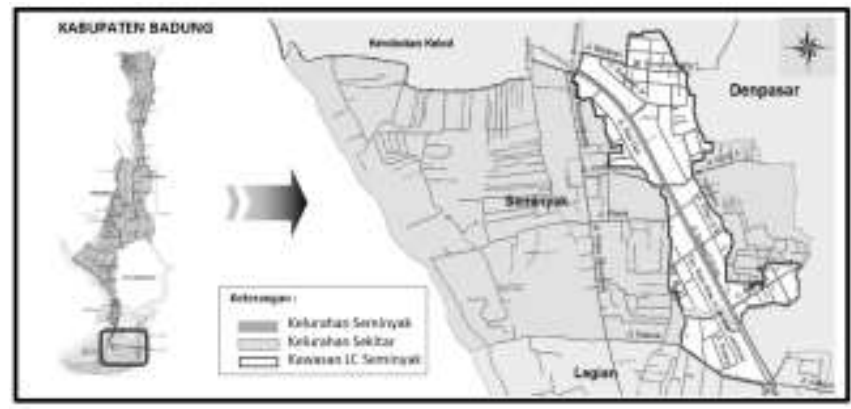

Fig. 1. Location Map of the LC Seminyak Area

Source: Badung Regency National Land Agency (2013)

\section{B. Normative Aspects}

Based on the Regional Regulation of Badung Regency number 26 of 2013 concerning the Badung Regency Spatial Plan, it can be seen that the regional development strategy in Badung Regency is broadly divided into three parts, namely the North Badung, Central Badung, and South Badung areas. For the South Badung area it was developed with the main function of tourism, so that it is clear that tourism functions are developing rapidly in this area.

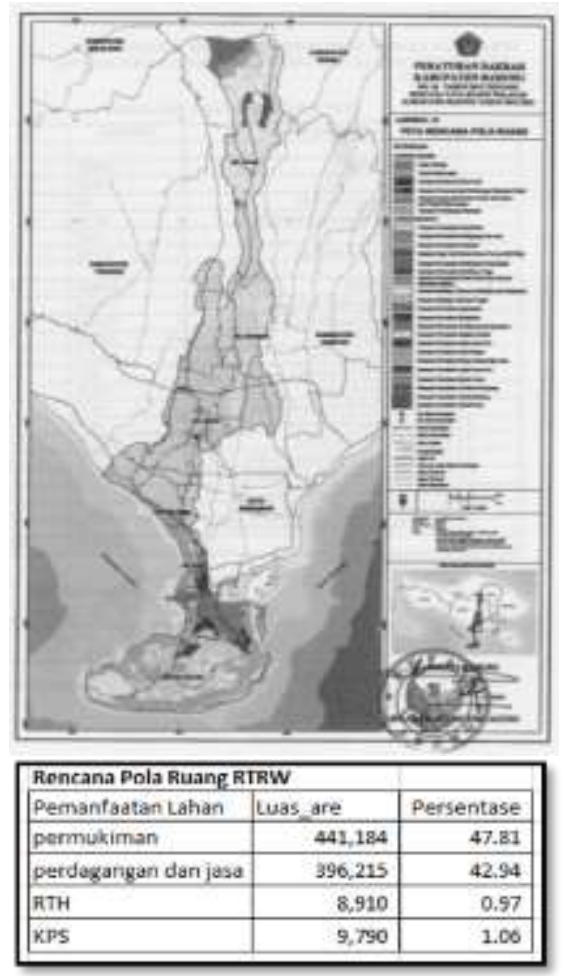

Fig. 2 Map of the Spatial Allotment Plan in the LC Seminyak Area Source: Badung Regency National Land Agency (2013)

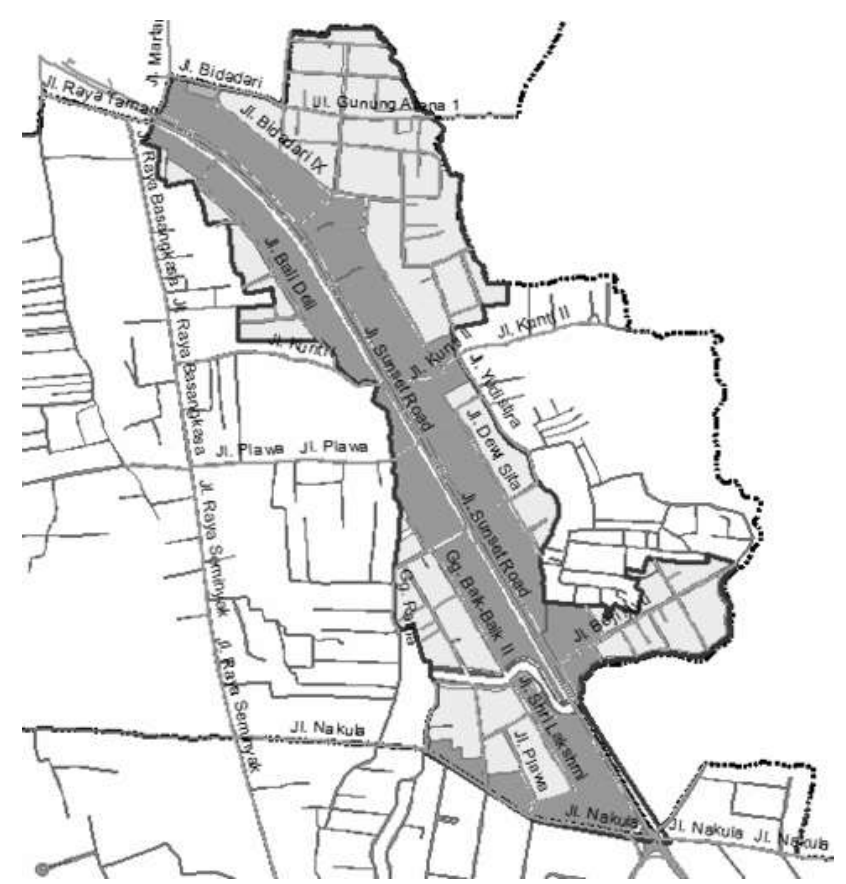

Fig. 3 Map of the Spatial Allotment Plan in the LC Seminyak Area Source: Badung Regency National Land Agency (2013)

\section{Development of Land Use in the LC Seminyak Area}

The appearance of land use can change according to changes in time in a certain period. Land use changes that occur in an area can be identified using remote sensing and geographic information systems. Remote sensing or what is often called remote sensing is a technique of obtaining information about objects, areas, or symptoms by analyzing data obtained using tools without direct contact with the object being studied [14]. Likewise, to determine the development of land use at the research location, remote sensing techniques are used, using time series imagery from Google Earth.

Prior to the implementation of land consolidation activities in Kelurahan Seminyak which began in 1995, this area was a fairly fertile rice field. In 1995 three subaks in Badung Regency, namely the Abianbase, Uluntanjung, and seminyak subaks, were designated as land consolidation areas (LC), through a Decree of the Badung Regent. The LC in question is a non-agricultural LC, namely an LC area which is designated as a residential area. The implementation of the LC activities lasted for 8 years and ended in July 2003. The results of the LC activities can be seen from the shape and location of the land parcels that are well-ordered and regular, the existence of land donations for development (STUP) made by LC participants. Furthermore, land use in the LC Seminyak area will be analyzed based on its suitability with the legalized regional spatial plan, namely the Badung Regency Regional Regulation Number 26 of 2013 concerning the RTRW of Badung Regency. 


\section{Utilization of Settlement Area Land}

The development of land use after land consolidation activities, especially in the area designated for settlement in the research location, has developed quite rapidly. Based on satellite imagery from Google Earth and observations at the research location, the area built up to 2018 reached $61.28 \%$ with an average area built annually of 1.6 hectares or $3.6 \%$. The most rapid development occurred between 2002 and 2009. The range of development of land use into built-up areas was relatively short for seven years with growth reaching 13.26 hectares, then in 2009 to 2014 the addition of built-up areas was 9.25 hectares. Between 2014 and 2018 the addition of the built-up area was $3.12 \mathrm{Ha}$ or an average addition of $0.8 \mathrm{Ha}$ annually. For more details, see table 1 and figure 3 .

TABLE I

Changes in Land Use in Perunyukan Settlement Areas

\begin{tabular}{cccc}
\hline Years & $\begin{array}{c}\text { Buildup } \\
\text { area } \\
\end{array}$ & \multicolumn{2}{c}{ Area growth is built } \\
\cline { 3 - 4 }$(\mathrm{m} 2)$ & Area & years \\
\hline 2002 & 13.993 & - & - \\
\hline 2009 & 146.679 & $132.686 \mathrm{~m} 2$ & $18.955 \mathrm{~m} 2$ \\
\hline 2014 & 239.203 & $92.524 \mathrm{~m} 2$ & $18.505 \mathrm{~m} 2$ \\
\hline 2018 & 270.390 & $31.187 \mathrm{~m} 2$ & $7.797 \mathrm{~m} 2$ \\
\hline
\end{tabular}

Kostof in Mubarok [15] classifies settlements into two types, namely planned settlements and unplanned settlements. A planned settlement is a planned settlement that is usually in the form of a grid, circle or polygon with radial road circulation and originates from the center of the settlement. The type of settlement in the LC Seminyak area is a planned settlement that is a mixture of settlement and tourist accommodation. This type develops spread in almost all areas of LC Seminyak. Based on the satellite imagery in 2018 and the results of observations to the research location, the most dominant use of land in the designated residential area is the use as tourist accommodation in the form of villas, either managed privately or with professional management. The land use as a villa is 18.01 ha or $44.09 \%$, while the use as a house is $6.6 \%$ or 2.70 ha. Empty land or land that is not used is still quite large, namely $\pm 13.18 \mathrm{Ha}$ or $32.26 \%$.

The land use map that has been overlaid with the spatial pattern plan map in the Badung Regency RTRW, can be seen in Figure 4. The darker color is the land use that is not in accordance with the spatial plan of the RTRW Badung Regency that has been determined. The data shows that there is quite a large mismatch of land use in residential areas. The deviation in land use is $46 \%$ against the spatial plan that has been determined. Land use includes villas, hotels and boarding houses that exceed the number of rooms stipulated, namely a maximum of 15 rooms. Meanwhile, $54 \%$ of suitable land uses are houses, shops, offices, schools, fields, including vacant land that has not been used.

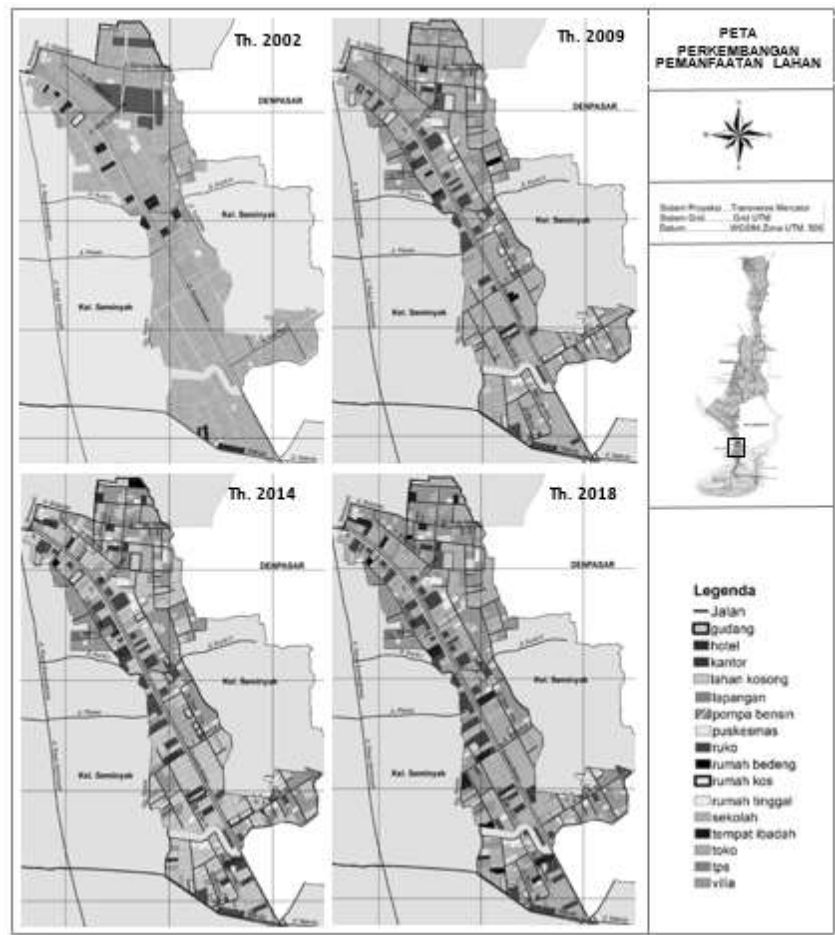

Fig. 3 Map of the Spatial Allotment Plan in the LC Seminyak Area Source: Badung Regency National Land Agency (2013)

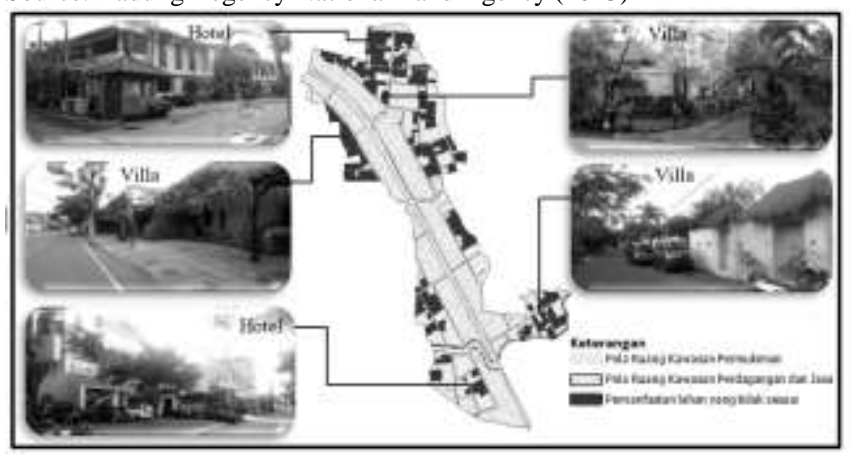

Fig. 4 Distribution of Land Use Inconsistent with the Allocation of Spaces

\section{E. Utilization of Trade and Service Zone Land}

The growth of spatial functions in the trade-services area after LC activities in Seminyak Village has increased from year to year. Until the end of 2018, land use in the trading and service area reached $20.10 \mathrm{Ha}$ or $56.61 \%$, with the use of shophouses and shops dominating. Other spatial functions that develop along Jalan Sunset Road are office and hotel warehouses. The use of land as houses and villas develops more on land plots that are inside or along environmental roads, such as Bali Deli Street, Periuk Street, Sri Laksmi Street, see Figure 5.

Yeates and Garner in Nisa and Haryanto [16] classify the characteristics of trade-services areas into three based on the location and scale of their services, namely: 1) Nucleatios is an area with grouped trade centers. The growth of these trading centers is generally located in places that have high accessibility, such as crossroads or neighborhood centers; 2) Ribbons is an area with trade along the way. The growth of these trade centers is generally located on main roads that are often traversed by 
the public by taking into account the maximum accessibility to the consumer society that they want to be served; 3 ) Specialized Areas are areas with special trading centers. Based on the distribution of functions in the service-trade area in the Seminyak LC Area, the characteristics of the service-trade area in the Seminyak LC Area can be categorized as Ribbons, as seen from the growth of trade centers on the main roads. This shows that the characteristics of the trade-service area are road-oriented, especially the main roads that have high accessibility, such as Jalan Sunset Road, Jalan Kunti, and Jalan Nakula. If viewed from its compliance with the Badung Regency Spatial Plan 2013-2033, in the area designated for trade and services in the LC Seminyak area, there is no deviation in land use from the regional spatial plan.

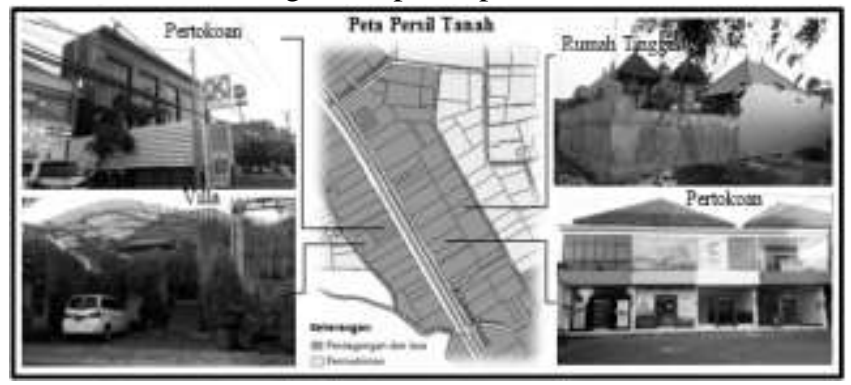

Fig. 5 Use of Land in the Trade and Service Zone

\section{F. Utilization of Green Open Space Area Land}

Green open space is typologically divided into four, namely physical, function, structure and ownership, while public RTH and private RTH are grouping RTH based on ownership [17]. Law No. 26 of 2007 concerning Spatial Planning mandates that urban spatial planning must contain plans for the provision and utilization of green open space with a minimum area of $30 \%$ of the total area. Urban green open space consists of public green open space and private green open space, where the proportion of green open space consists of $20 \%$ public green open space and $10 \%$ consists of private green open space. Utilization of the house yard and garden can be used as private green open space. Utilization of green open space is prioritized on the main function of the area and environmental preservation; RTH can also function as a place for sports, recreation, parking for vehicles, pedestrians; and can function as disaster mitigation in the form of evacuation routes or a gathering place for the masses.

Based on the RTRW of Badung Regency, the area designated as Green Open Space is 79.37 acres or 1\% of the area of LC Seminyak. This area is very far from the required provisions. The results showed that the existing land use conditions in the RTH area in LC Seminyak in 2018, were mostly parks in the middle median of Jalan Sunset Road and parks in the middle of the junction of Jalan Sri Laksmi and Jalan Nakula with an area of 58.66 are or $74 \%$. Other uses besides those that are permitted are also developing in the RTH area. Changes in the use of RTH land have developed into villas and shops. Land use irregularities with the stipulated RTH plan occurred on Jalan Bidadari, with the area of change reaching $26 \%$ of the area allocated for RTH.

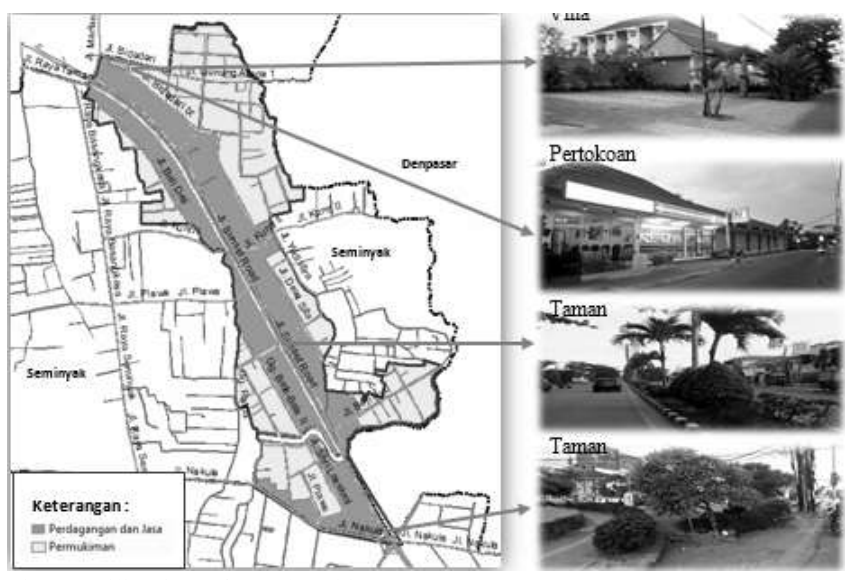

Fig. 6 Utilization of Land and in RTH Areas

According to the Regulation of the Minister of Public Works number 05 / PRT / M / 2008 concerning guidelines for the provision and utilization of green open space in urban areas, it states that public green open space is RTH owned and managed by the city / regency regional government which is used for the benefit of the community in general. . The conversion of land use from green open space to other uses is due to the determination of public green open space plans that are carried out on private land owned by the community, as well as the lack of participation and socialization of green open space plans, especially those involving private community lands.

\section{G. Law Enforcement Factors}

The law enforcement factor is one of the factors that causes changes in land use that occur in the research location. Spatial planning is a system consisting of spatial planning, space utilization and spatial use control. Land use change is a new use of land that is not in accordance with the predetermined spatial plan. Weak law enforcement by the government and low implementation of regulations have resulted in the emergence of negative effects and irregular spatial use patterns [17]. This weak law enforcement is a weakness in the aspect of the implementation of spatial use control [18]. In implementing spatial planning regulations, consistency from the government is needed. The occurrence of irregularities in land use at the research location is caused by weak control over spatial use and inadequate law enforcement by local governments. The tolerant and less assertive attitude of government officials in law enforcement seems to provide opportunities for the community not to comply with applicable spatial planning regulations.

The low level of public understanding of the spatial planning regulations and the lack of socialization of the applicable spatial planning regulations have resulted in land use occurring that does not heed the regulations set by the government. Generally, they build to follow a growing 
trend, without knowing the designation of the space in the area. Moreover, the lack of periodic supervision from the government on the use of space that occurs. This is a factor driving the increase of irregularities in land use in the research location.

\section{H. Environment Factors}

Land use is influenced by accessibility and land prices, where in general, land prices are strongly influenced by the land environment (Rusdi, 2013). Research shows that environmental factors have a significant role in land use change in the LC Seminyak area. LC activities have transformed agricultural areas into non-agricultural areas. The main objective of land consolidation activities in Kelurahan Seminyak is to provide land for road construction with community participation. The result of this LC activity is an increase in land value as a result of the increase in environmental quality with the arrangement of land parcels and is equipped with road infrastructure, environmental facilities, and other supports.

The LC Seminyak area has a very strategic location when viewed from its accessibility to the centers of government, economy and tourism. The potential of seminyak village in the tourism sector has a strong influence on the development of the LC Seminyak area. Changes in land use into tourist accommodation are strongly influenced by the strategic location of the LC Seminyak area close to Kuta tourism objects, the location and shape of the area which is regular and is equipped with adequate infrastructure. This is in accordance with Colby's theory in Yunus [19], the LC Seminyak area has centripetal strength, namely site forces where the LC Seminyak area has a strategic location, and functional prestige forces where the LC Area has environmental quality and high enough land value.

\section{Economic Factors}

Increasing income is a classic reason for land owners to make land use changes [20] Economic factors are also one of the factors that trigger changes in land use in the research location. Prior to land consolidation activities, the LC Seminyak area was a fertile agricultural area. In 1995, the activities of consolidating urban land in this area as settlements began. Land owners who only have farming expertise are starting to feel the impact of this program. As a consequence, land owners are no longer able to cultivate land for farming, due to the cut off of the irrigation channel due to the impact of the LC activities. In addition, the economic hardship experienced by land owners is due to increased needs and living costs, such as: education costs, family health, and fulfillment of daily needs. To maintain income, land owners prefer to rent out part of their land and partially use it themselves for activities that are more profitable financially.

This indirectly results in changes in land use, either by the land owner itself, or through the process of renting or buying and selling to other parties. Several land owners revealed that the land they owned was quite extensive, some of the land was rented out for villas and partly managed by building boarding houses to meet family needs. Economically, this decision was taken, to make a more profitable financial contribution. Yunus [19] states that land value and land use have a very close relationship, the higher the accessibility of a location, the higher the land value. The land use orientation develops based on the assessment of the land. On this basis, land use will be selected according to the ability of the functions to pay for the land. To meet the increasing needs of life, with high land values or land rents, land owners use their land for functions that can provide greater economic benefits.

\section{J. Social and Cultural Factors}

Population growth in Kelurahan Seminyak during the last ten years has continued to increase, both naturally due to growth rates and non-natural growth due to migration or population displacement. The Central Bureau of Statistics of Badung Regency recorded that the total population in Kelurahan Seminyak in 2016 was 3,750 people with a population of 1,858 men and 1,892 women with a population density of 1415 people / $\mathrm{km}^{2}$. High population growth will result in an increased need for space or land, both as a place to live, infrastructure and public space [21]. This resulted in the expansion or compaction of the built land. Land locations that are considered strategic are a priority for land use. Indications of deviations in spatial use that occur can be seen from land use activities that no longer pay attention to land use, but pay more attention to economic aspects and market needs.

Changes in the mindset of an increasingly modern society have led to changes in land use patterns, including for homes. The community no longer builds houses that require large enough land with the Asta Kosala Kosali concept, with separate bale layouts according to their allotment. People are more likely to build modern houses, taking into account the space in one house that is considered more practical and in accordance with their needs. They are more likely to build houses that consider practicality, both time and cost in maintaining the house, even though the land they own is still quite large. They argue that the remaining land they own can be rented out or built tourist accommodation so that it is more profitable financially.

\section{CONCLUSION}

LC activities in Seminyak Village began in 1995 with a Decree of the Badung Regent and ended in 2003. Based on the RTRW of Badung Regency, the Seminyak LC Area was planned as an area designated for urban settlements and regional scale service trade. Most of the transitional forms of land use change are in the Allocated Settlement Areas and Green Open Space Areas. The dominant land use change in the LC Seminyak area is the use for villas, boarding houses and hotels.

The factors underlying land use change can be grouped 
into four, namely: law enforcement factors, environmental factors, economic factors and socio-cultural factors. Law enforcement factors behind land use change are weak law enforcement by the government, and lack of socialization of spatial planning regulations to the community. Environmental factors that affect land use change are strategic locations and the construction of infrastructure in the research location. Economic factors include the desire of landowners to increase their income, while the sociocultural factors behind changes in land use are population growth and changes in people's perceptions of houses.

\section{REFERENCES}

[1] Mulyanti, W. (2015). Pengaruh Konsolidasi Lahan Perkotaan terhadap Harga Tanah di Ringintelu, Kelurahan Kalipancur-Kota Semarang. Jurnal Pembangunan Wilayah \& Kota, 11(1), 63-75.

[2] Sumardjono, M. S. (2006). Kebijakan pertanahan: antara regulasi dan implementasi: Penerbit Buku Kompas.

[3] Hasni. (2008). Hukum Penataan Ruang dan Penatagunaan Tanah. Jakarta: Rajagrafindo Persada.

[4] Budiyanto, H. (2018). Manfaat Penggunaan Metoda Konsolidasi Tanah Dalam Rangka Penataan Wilayah Perkotaan Mintakat: Jurnal Arsitektur, 2(1).

[5] Tunjungsari, K. R. S., I Made Trisna; Parwati, Komang Shanty Muni. (2017). Persepsi Masyarakat Kuta Terhadap Dampak Pembangunan Hotel Berkonsep City Hotel Di Sunset Road Kuta Bali. . Jurnal Kepariwisataan dan Hospitalitas, 1(2), 151-164.

[6] Sugiyono. (2014). Metode Penelitian Kuantitatif, Kualitatif, dan R \& D. Bandung: Alfabeta.

[7] Anitasari, R. F. (2008). Pelaksanaan Alih Fungsi Tanah Pertanian Untuk Pembangunan Perumahan di Kota Semarang. program Pascasarjana Universitas Diponegoro.

[8] Ariani, R. (2011). Analisis Land Rent Sawah Irigasi dan Lahan Terbangun di Kecamatan Depok Kabupaten Sleman. Institut Pertanian Bogor, Bogor.

[9] Sadyohutomo, M. (2008). Manajemen kota dan wilayah: realita \& tantangan. Jakarta: Bumi Aksara

[10] Kusrini, S., Hardoyo, Su Rito. (2011). Perubahan Penggunaan Lahan dan Faktor yang Mempengaruhinya di Kecamatan Gunungpati Kota Semarang. Majalah Geografi Indonesia, 25(1), 25-40.

[11] Kustiwan, I. (1997). Permasalahan Konversi Lahan Pertanian Dan Implikasinya Terhadap Penataan Ruang Wilayah studi Kasus: Wilayah Pantura Jawa Barat. Journal of Regional and City Planning, 8(1), 49-60.

[12] Lestari, T. (2010). Konversi Lahan Pertanian dan Perubahan Taraf Hidup Rumahtangga Petani: Kasus Pembangunan Perumahan X di Kampung Cibeureum Sunting dan Kampung Pabuaran, Kelurahan Mulyaharja, Kecamatan Bogor Selatan, Kota Bogor, Provinsi Jawa Barat. Institut Pertanian Bogor, Bogor

[13] Yunus, H. S. (2008). Dinamika Wilayah Peri-Urban Determinan Masa Depan Kota. Yogyakarta. Yogyakarta: Pustaka Pelajar.

[14] Syah, A. F. (2010). Penginderaan jauh dan aplikasinya di wilayah pesisir dan lautan. Jurnal Kelautan: Indonesian Journal of Marine Science and Technology, 3(1), 18-28.

[15] Mubarok, J., \& Murtini, T. W. (2019). Pola Permukiman Pesantren Darul 'Ulum Peterongan Jombang Pada Masa Kejayaan Di Tahun 1975. ARSITEKTURA, 17(2), 185-194.

[16] Nisa, A. F., \& Haryanto, R. (2014). Kajian Keberadaan Wisata Belanja Malioboro terhadap Pertumbuhan Jasa Akomodasi di Jalan Sosrowijayan dan Jalan Dagen. Teknik PWK (Perencanaan Wilayah Kota), 3(4), 933-948.

[17] Dwiyanto, A. (2009). Kuantitas dan kualitas ruang terbuka hijau di permukiman perkotaan. Teknik, 30(2), 88-92.

[18] Eko, T., \& Rahayu, S. (2012). Perubahan penggunaan lahan dan kesesuaiannya terhadap RDTR di wilayah peri-urban studi kasus: Kecamatan Mlati. Jurnal Pembangunan Wilayah dan Kota, 8(4), 330-340.
[19] Yunus, H. S. (2015). Struktur Tata Ruang Kota. Yogyakarta: Pustaka Pelajar.

[20] Sajow, H. S. C., Rondonuwu, D. M., \& Makainas, I. (2016). Perubahan Fungsi Lahan Di Koridor Segitigamapanget-Talawaan. SPASIAL, 3(2), 40-48.

[21] Wesnawa, I. G. A. (2010). Penerapan Konsep Tri Hita Karana Dalam Lingkungan permukiman Perdesaan (Kasus Kabupaten Badung Provinsi Bali). Bumi Lestari Journal of Environment, 10(2) 